\title{
IMPACT AND SIGNIFICANCE OF STATE-OWNED ENTERPRISE RESTRUCTURING IN CHINA
}

\section{Ross Garnaut, Ligang Song and Yang Yao}

The transformation of China's state-owned enterprises (SOEs) over the past decade has resulted in remarkable changes to the structure of the Chinese economy. Gaizhi, the Chinese term meaning "transforming the system", has become a major phenomenon in most parts of the country and in many cases has involved privatization. The term gaizhi is used to describe any form of structural change to a firm, including public offering of shares, internal restructuring, bankruptcy and reorganization, employee shareholding, open sales, leasing and joint ventures. Unlike the mass privatization programs that occurred in Eastern Europe and the former Soviet Union, the Chinese government's gaizhi programs have been gradual and low-profile. However, the significance of the Chinese reform should not be underestimated.

Based on a 683-enterprise survey conducted in 11 cities in 2002,' this paper reviews the trends of privatization, discusses the forms of gaizhi, analyzes the issues emerging in the process of gaizhi, especially the handling of state assets and land-use rights and re-employment, and compares firm performance before and after gaizhi. The aim of this paper is to give the reader an overview of the restructuring process in China, and to analyze some of the key issues.

Several key conclusions have emerged from the study. First, restructuring has become more oriented towards privatization over recent years. Privatization here means an increase in the share of ownership held by private investors. Second, the so-called "loss of state assets" has occurred mainly in the form of

* We are grateful for the useful and constructive comments made by the two anonymous referees and to the editors of The China Journal for providing additional insightful comments and relevant references. We thank the International Finance Corporation for allowing us to use the survey data in this paper. The views expressed in this paper are ours.

The authors are principal researchers in this survey. The survey adopted a research strategy that combines structured questionnaires distributed to firms selected by random sampling with face-to-face interviews with government officials and enterprise management selected to provide insights into the privatization process and its outcomes. While the sampling provides quantitative data, the interviews reveal rich qualitative information regarding different government policies and various problems that have been encountered in gaizhi. 
price discounts when selling state assets. Local governments gave discounts and in many cases land-use rights to new owners in exchange for their consent not to sack many workers. Third, restructured or gaizhi firms did sack more workers in the year the gaizhi took place, but subsequently they maintained a slower rate of employment reduction than pure SOEs. Fourth, gaizhi, especially restructuring with privatization, has hardened firms' budget constraint with banks, but has not been effective in hardening firms' budget constraint with the government. Finally, gaizhi and privatization have significantly improved firms' profitability, but have not raised investment rates or labor productivity (measured by per-worker sales). This result shows that gaizhi and privatization have led firms to abandon the expansionary business model characterizing old-style SOEs and to adopt a new business model that gives top priority to cost savings. ${ }^{2}$

The paper is organized as follows. The next section reviews China's recent history of SOE reforms. It provides data to gauge the extent of privatization in China. Then, after describing the survey, it analyzes the forms of gaizhi and the pace of privatization using the survey data. We then discuss the terms of transfer of state assets and the extent of price discounts in the process of gaizhi; analyze the effects of restructuring on employment, giving specific attention to the financial arrangements for worker settlement; and finally consider the impact of restructuring on firms' financial discipline and economic performance.

\section{Recent SOE Reforms in China}

Reform of China's state-owned enterprises has been much discussed since urban reforms began in 1984. Although there were early calls for privatizing the SOEs, the government's emphasis was initially on boosting performance by changing the SOEs' internal governance and improving the market environment in which they operated. Inspired by the success of the rural household responsibility system, the government introduced a contracting system into the state industrial sector, requiring SOE managers to meet targets for sales, profitability, rates of investment and so on, in return for the enterprise retaining a share of the profits. Studies have found that the contracting system had improved firm performance in the 1980 s. $^{3}$ The main problem with this system was that managers were rewarded for their successes but not punished for their failures. By the end of the 1980s,

For a more comprehensive coverage of these issues, see Ross Garnaut, Ligang Song, Stoyan Tenev and Yang Yao, China's Ownership Transformation: Process, Outcomes, Prospects (Washington: International Finance Corporation; the World Bank, 2005).

3 Roger Gordon and Wei Li, "The Change in Productivity of Chinese State Enterprises, 19831987", Journal of Productivity Analysis, Vol. 6, No. 1 (1995), pp. 5-26; Theodore Groves, Yongmiao Hong, John McMillan and Barry Naughton, "Autonomy and Incentives in Chinese State Enterprises", Quarterly Journal of Economics, Vol. 109, No. 1 (1994), pp. 183-209; Theodore Groves, Yongmiao Hong, John McMillan and Barry Naughton, "China's Evolving Managerial Labor Market", Journal of Political Economy, Vol. 103, No. 4 (1995), pp. 873-92; Wei Li, "The Impact of Economic Reform on the Performance of Chinese State Enterprises, 1980-1989", Journal of Political Economy, Vol. 105, No. 5 (1997), pp. 1080106. 
leasing was adopted as another approach to reforming SOEs. The first significant lease contract involved the Wuhan Motor Engine Factory in 1986, when three people put up 34,000 yuan as collateral to lease the factory. In May 1988 the State Council issued a regulation on the leasing of small SOEs. ${ }^{4} \mathrm{~A}$ direct consequence was that managers could be recruited from outside the enterprise.

Private shareholding was first introduced into SOEs in three Guangzhou firms in 1986, when the employees bought 30 per cent of their firms' shares. The first large SOE in which private entities purchased shares was the Shenyang Motor Corporation, which became Shenyang Jinbei Motors when it issued shares to the public in August $1988 .^{S}$ The opening of the Shenzhen Stock Exchange in 1990 and the Shanghai Stock Exchange in 1991 enabled a limited number of SOEs to issue shares to the public. Large-scale privatization only started after Deng Xiaoping's famous visit to southern China in 1992. As with many other reform initiatives, privatization started at the local level and was later sanctioned by the central government.

The most important impetus for privatization in the localities was the large amount of debt built up by the state sector. The level of debt was a more pressing problem in small cities. For example, in Zhucheng city of Shandong province, 103 of the 150 SOEs were in the red at the end of 1992, with losses amounting to 147 million yuan--equivalent to the city government's revenue over 18 months. ${ }^{6}$ The Shunde municipal government was also encountering a debt problem when it first started privatizing its SOEs in 1992. ${ }^{7}$ It was not a coincidence that Shunde and Zhucheng were the two cities that pioneered the privatization of all their state and collective firms. ${ }^{8}$

In 1995, after extensive discussions, the central government decided on the policy of zhuada fangxiao, or "keep the large and let the small go". The state decided to retain ownership of 500 to 1,000 large state firms and to allow smaller firms to be leased or sold. ${ }^{9}$ There were good reasons for this decision. In 1997 the

"Guanyu xiaoxing guoyou gongye qiye zulin de zhanxing guiding" (Tentative Regulations on the Lease of Small State-owned Industrial Enterprises), State Council, 20 May 1988.

$5 \quad$ Xiao Zhao, "Jingzheng, gonggong xuanze he zhidu bianqian" (Competition, Public Choice and Institutional Change), CCER Working Paper No. C1999025, 1999, Beijing University.

6 Xiao Zhao, "Jingzheng, gonggong xuanze", p. 21.

7 Yang Yao, "Privatising the Small SOEs", Chapter 7 in Ross Garnaut and Ligang Song (eds), China's Third Economic Transformation: the Rise of the Private Economy (Routledge: London, 2004), pp. 91-101.

8 Shao'an Huang and Jian Wei, "A Research Report on State-Owned SMEs in Zhucheng”, mimeo, School of Economics, Shangdong University, 2001; Yang Yao, "Privatising the Small SOEs".

9 In 1994, the State Economic and Trade Commission, sent a report, "Guanyu gaohuo xiaoxing guoyou qiye de jianyi" (Suggestions on Revitalizing Small State-owned Enterprises), to then Vice-Premier Wu Bangguo, who was in charge of enterprise reforms. In September 1995 the policy was formally announced by the Central Committee of the Chinese Communist Party in one of its plenaries and went forward as a suggestion for the 
500 largest state firms held 37 per cent of the state's industrial assets, contributed 46 per cent of all taxes collected from state firms, and totalled 63 per cent of the state sector's profits. Small firms owned by local governments had been performing poorly. In 1995, 72.5 per cent of local firms were unprofitable, but only 24.3 per cent of firms owned by the central government. ${ }^{10}$ As Vice-Premier Wu Bangguo said in a speech in December 1997, "Control of the [500] largest firms means we have a control of the largest chunk of the state economy"."1

From the "let the small go" part of the policy came the term "gaizhi", which in Chinese means "changing the system", but which has increasingly served as a euphemism for privatization, especially in the case of small firms. By the end of 1998 , more than 80 per cent of state and collective firms at the level of the county or below had gone through gaizhi. ${ }^{12}$ In cities, gaizhi has occurred in two waves. Reform started in the mid-1990s and at first followed the model of employeeshareholding adopted by Shunde and Zhucheng. When these two cities abandoned this model and moved to share concentration and management buyouts in 1997, other cities followed suit. Management buy-out has been the most common model in the second wave of gaizhi and has spread to large firms, such as the SOEs listed on the stock market. Privatization has been accepted as the key to urban reform, and the slogan "the state retreats and the private sector moves forward" has become common in many cities.

\section{Figure 1: Firms with State Ownership Control: A Comparison Between National and Sample Average (Per cent).}

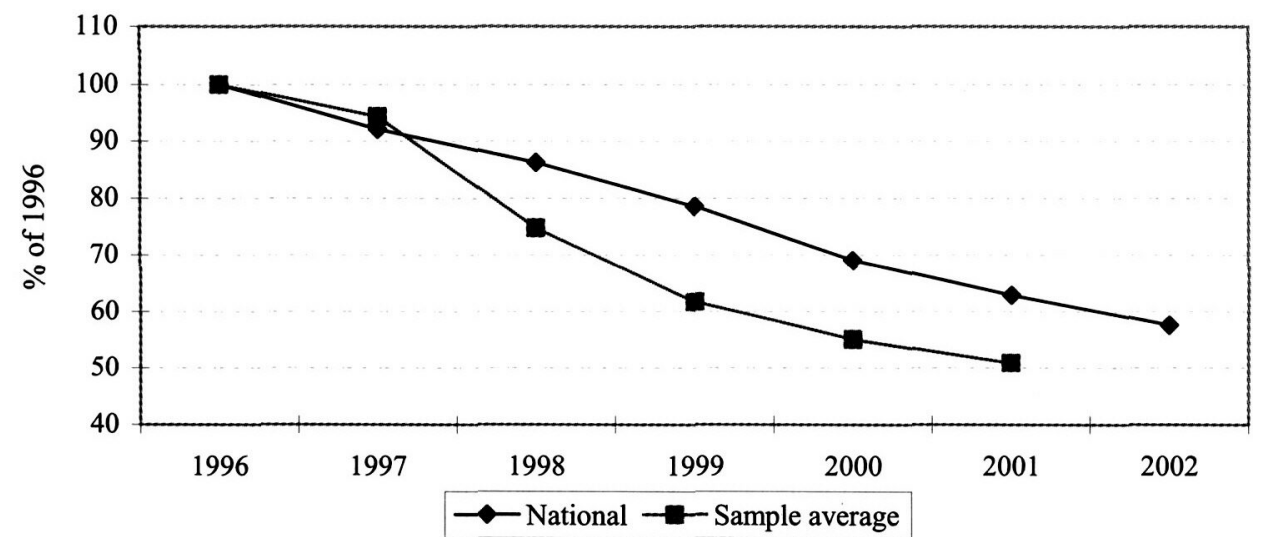

Sources: China Fiscal Statistical Yearbook: 1997-2003 (Beijing, various years) and the survey data.

Ninth Five-Year Plan.

10 Xiao Zhao, “Jingzheng, gonggong xuanze”, p. 18.

11 Xiao Zhao, “Jingzheng, gonggong xuanze", p. 25.

12 Xiao Zhao, "Jingzheng, gonggong xuanze", p. 29. 
Figure 1 shows the trend of privatization in the whole country for the period 1996-2002 and in the 11 sample cities for the period 1996-2001. The figure takes the number of state-controlled firms-defined as those with more than 50 per cent of their shares controlled by the governmentin 1996 as 100 per cent, and shows the percentage that remained in public ownership in each subsequent year. On the assumption that the reduction in the number of state-owned firms reflected privatization, ${ }^{13}$ more than 40 per cent of the SOEs were privatized in China during the period 19962002. The pace of privatization was faster in the sample cities. Only about half of the firms controlled by the state in 1996 remained in 2001. Statistically, the falling numbers of SOEs can also be partially explained by a growing number of mergers and acquisitions within the state sector and the use of new categories of firms such as corporatized SOEs. It is noteworthy that 1997 was a turning point for the sample cities. Privatization accelerated considerably following Shunde's and Zhucheng's second wave of gaizhi which aimed at consolidating shares in the hands of the management.

There was a debate in 1998-99 on whether management buy-outs had resulted in a "loss of state assets", ${ }^{14}$ that is, whether SOE assets had been appropriated by the management. The debate did not have a real impact on the pace of privatization, although the word "privatization" has since disappeared from both official and public discourse and been replaced by gaizhi.

The trend of privatization shown in Figure 1 is also confirmed by other survey studies. A national survey in 1998 showed that one quarter of China's 87,000 industrial SOEs had experienced gaizhi and another quarter planned to undertake some form of gaizhi. Among the gaizhi firms, $60-70$ per cent had been partially or fully privatized. ${ }^{15}$ A 2002 national survey of industrial SOEs estimated that 86 per cent had been through gaizhi by the end of 2001 , and about 70 per cent had been partially or fully privatized. ${ }^{16}$

13 This assumption is subject to two qualifications. First, some firms may have vanished not because of privatization but because of simple closing-up, which implies that our measure of privatization is upward-biased. Second, new SOEs may be established over the period, which implies that the measure is downward-biased.

14 Qin Hui (1998), Jiangzhe xiangzhen qiye zhuanzhi anli yanjiu (Case Studies of TVE Ownership Transformation in Jiangsu and Zhejiang) (Hong Kong: Chinese University of Hong Kong, 1998).

15 Unpublished report of the National Bureau of Statistics.

16 Unpublished report of the State Economic and Trade Commission. 
Figure 2: Locations of the 11 Sample Cities

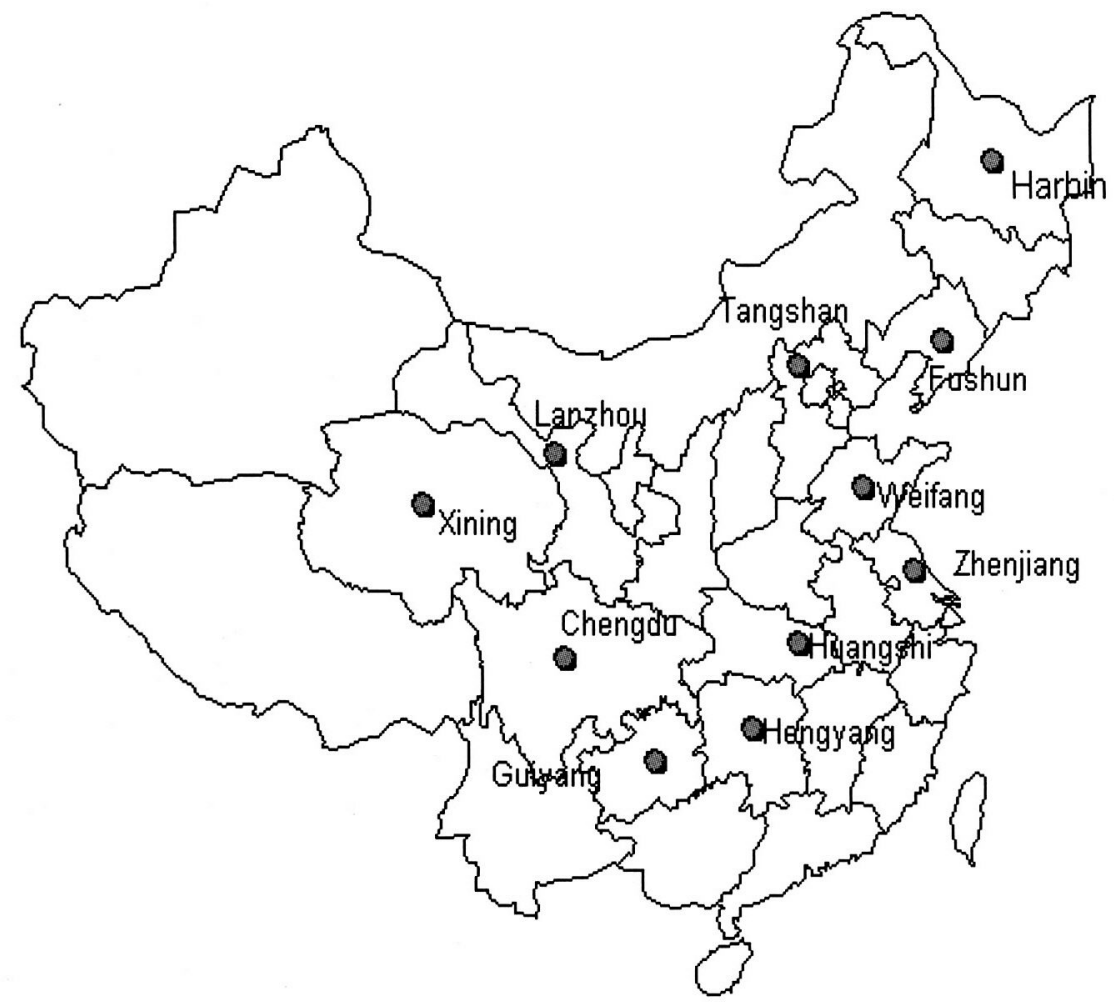

\section{The Survey}

The survey was funded by the International Finance Corporation and was conducted in the spring of 2002. The 11 sample cities are, from north to south: Harbin, Fushun, Tangshan, Lanzhou, Weifang, Xining, Zhenjiang, Huangshi, Chengdu, Hengyang and Guiyang. They represent a wide spectrum of regions, levels of economic development and conditions for SOEs. The design of the survey aimed at sampling all the SOEs managed by the city governments at the end of 1995 . The year 1995 was chosen because large-scale privatization began in the mid-1990s. However, not all firms returned the questionnaires. The possibility of bias in sample selection thus presents a potential problem that was considered in the analysis of survey results. Table 1 shows the distribution of the 683 sample firms in the cities. 
Table 1: Distribution and Statistics of the Sample Firms

\begin{tabular}{|l|r|r|r|r|r|r|r|r|r|r|r|r|}
\hline & Harbin & Fushun & Tangshan & Weifang & Lanzhou & Xining & Huangshi & Guiyang & Zhenjiang & Hengyang & Chengdu & Total \\
\hline $\begin{array}{l}\text { \# of } \\
\text { firms }\end{array}$ & 120 & 10 & 59 & 30 & 39 & 26 & 79 & 149 & 70 & 57 & 44 & 683 \\
\hline$\%$ & 17.6 & 1.5 & 8.6 & 4.4 & 5.7 & 3.8 & 11.6 & 21.8 & 10.2 & 8.3 & 6.4 & 100.0 \\
\hline \begin{tabular}{l} 
2001 statistics \\
\hline Size
\end{tabular} & 302.9 & 475.5 & 1361.2 & 1049.3 & 318.4 & 383.1 & 345.0 & 515.7 & 433.8 & 330.5 & 119.4 & 463.7 \\
\hline $\begin{array}{l}\text { Gross } \\
\text { value } \\
\text { of } \\
\text { assets } \\
\text { (mil. } \\
\text { yuan) }\end{array}$ & 58.0 & 82.7 & 76.5 & 80.6 & 54.8 & 71.9 & 47.1 & 42.9 & 40.2 & 48.0 & 10.7 & 51.2 \\
\hline $\begin{array}{l}\text { Per- } \\
\text { worker } \\
\text { assets } \\
(1000 \\
\text { yuan) }\end{array}$ & 623.6 & 677.4 & 229.2 & 123.4 & 401.0 & 182.5 & 293.1 & 118.5 & 244.1 & 665.7 & 142.9 & 414.4 \\
\hline $\begin{array}{l}\text { Profit } \\
\text { rate } \\
\text { (\%) }\end{array}$ & -2.3 & -2.8 & -0.7 & 3.1 & -3.3 & 0.4 & 0.1 & 0.7 & -2.5 & -1.2 & 0.3 & -0.01 \\
\hline
\end{tabular}

1. Size is the average number of on-duty workers.

2. Assets include fixed capital, working capital, account receivable and several miscellaneous categories.

3. Profit rate is the return to gross assets, that is, it is defined as pre-tax profit divided by the gross value of assets.

On average, the sample firms were of medium size, but some were quite large, employing close to 10,000 workers. In fact, the average size of the sample firms was more than double the national average of 204 workers in the same year. This is because the sample was drawn from firms managed by the city government and did not include firms managed by city districts and counties, which are usually smaller. Accordingly, the sample firms were quite "heavy" in the sense that they were highly capital intensive. On average, per worker assets were 414,400 yuan, most of which were fixed and working capital. Firms in Harbin, Fushun, Lanzhou and Hengyang were particularly "heavy", as these four cities have a concentration of capitalintensive industries. Many of these industries were undergoing painful restructuring, so it is not surprising that firms in these four cities on average registered a loss. Firms in two other cities, Tangshan and Zhenjiang, also had negative average profit rates. Responding firms in the other five cities had positive profit rates. On average, firms in the sample roughly broke even. It was a tough time in the several years after the Asian financial crisis.

\section{Forms of Gaizhi and the Extent of Privatization}

Different forms of gaizhi lead to different outcomes. Public offering, for example, does not change the state's control because the Chinese law requires that, in this process, the state retains the majority of the shares. Internal restructuring does not change the ownership of the assets, but 
involves reorganization, splitting, debt-equity swap and other restructuring measures within the firm. China's Bankruptcy Law only applies to SOEs. It was not widely applied until the mid-1990s, when the central government began to adopt bankruptcy as a means to restructure SOEs. ${ }^{17}$ An ordinary bankruptcy in a market economy would result in the bankrupt firm being dissolved, or at least being subject to fundamental change in ownership and management. But in many recently reported cases, bankrupt firms have continued operating with the same management. This false bankruptcy involves the firm entering bankruptcy and writing off its debts. But it does often result in diversification of the ownership of the firm, leading to partial or full privatization.

Employee-shareholding has been by far the most popular form of gaizhi throughout the country. Although proven to be a sub-optimal arrangement in other transitional countries, ${ }^{18}$ this form of gaizhi carried the least political risk in the early stage of reform. Open sale has become more popular in recent years. The firm is openly sold to insiders or outsiders, sometimes through auction. This is the most radical form of privatization because it can involve the transfer of the firm to a single private owner or a management group. The lease contracts now commonly used in gaizhi are quite different from those adopted in the early years of SOE reform. Early lease contracts acted as incentives within the SOE, but now they are used as a substitute for open sale when the buyer(s) do not have cash to buy the firm. Finally, forming a joint venture or merging with a domestic or foreign firm is another approach to gaizhi. This type of gaizhi helps the firm obtain long-term access to capital and technology.

In the sample of 683 firms, 375 reported that they had been subject to gaizhi by the spring of 2002 . Table 2 provides a breakdown of the gaizhi cases by type and city. It is evident that the southern and southwest cities, Chengdu, Weifang, Huangshi and Zhenjiang in particular, were more likely to adopt employee-shareholding and open sales while the northern cities were more likely to take internal restructuring and bankruptcy. This is largely due to the high concentration and scale of SOEs in the northeast region in comparison with the south where the private sector is relatively more developed and market environments are more competitive. Among the gaizhi firms, a total 70 per cent of gaizhi cases involved the transfer of ownership from the state to private hands.

17 Shanwen Gao and Yang Yao, "Implementation of Socially Optimal Outcomes in the Process of Dissolving Public Enterprises in China", China Economic Review, Vol. 10, No. 1 (1999), pp. 41-58.

18 Simeon Djankov and Peter Murrell, "Enterprise Restructuring in Transition: A Quantitative Survey", Journal of Economic Literature, Vol. 40, No. 3 (2002), pp. 739-792. 
Table 2: Forms of Gaizhi by City (Number and Percentage)

\begin{tabular}{|c|c|c|c|c|c|c|c|c|}
\hline & $\begin{array}{l}\text { Number } \\
\text { of gaizhi }\end{array}$ & $\begin{array}{l}\text { Public } \\
\text { offering }\end{array}$ & $\begin{array}{l}\text { Internal } \\
\text { restructuring }\end{array}$ & & $\begin{array}{l}\text { Employee } \\
\text { shareholding }\end{array}$ & $\begin{array}{l}\text { Open } \\
\text { sales }\end{array}$ & Leasing & $\begin{array}{l}\text { Joint } \\
\text { venture }\end{array}$ \\
\hline Harbin & 40 & 7.5 & 47.5 & 2.5 & 22.5 & 10.0 & 10.0 & 0.0 \\
\hline Fushun & 10 & 0.0 & 40.0 & 20.0 & 20.0 & 0.0 & 20.0 & 0.0 \\
\hline Tangshan & 57 & 8.8 & 26.3 & 10.5 & 15.8 & 15.8 & 17.5 & 7.0 \\
\hline Weifang & 34 & 14.7 & 14.7 & 11.8 & 50.0 & 2.9 & 0.0 & 5.9 \\
\hline Lanzhou & 11 & 0.0 & 9.1 & 54.5 & 27.3 & 9.1 & 0.0 & 0.0 \\
\hline Xining & 18 & 11.1 & 22.2 & 50.0 & 16.7 & 0.0 & 0.0 & 0.0 \\
\hline Huangshi & 54 & 7.4 & 11.1 & 5.6 & 38.9 & 22.2 & 13.0 & 1.9 \\
\hline Guiyang & 41 & 4.9 & 26.8 & 7.3 & 19.5 & 19.5 & 17.1 & 4.9 \\
\hline Zhenjiang & & 8.9 & 26.7 & 2.2 & 44.4 & 2.2 & 6.7 & 8.9 \\
\hline Hengyang & & 4.1 & 16.3 & 16.3 & 6.1 & 6.1 & 49.0 & 2.0 \\
\hline Chengdu & 21 & 4.8 & 14.3 & 0.0 & 38.1 & 38.1 & 4.8 & 0.0 \\
\hline Total & 380 & 7.4 & 23.2 & 11.3 & 27.1 & 12.4 & 15.3 & 3.7 \\
\hline
\end{tabular}

Source: Survey.

Of the 85 cases of internal restructuring, 62 per cent of SOEs were incorporated, that is, restructured as companies under the law, 19 per cent were new establishments emerging from the old firms, 8 per cent arranged a debtequity swap, 6 per cent had new investors, and the remaining 5 per cent were unclassified. Evidence from other transitional countries suggests that some incorporated SOEs perform better than other firms. This may be because firmspecific characteristics such as pre-privatization performance and firm size were not controlled for in these studies. It is quite possible that the government is more reluctant to privatize larger and better performing SOEs.

Of the 103 cases of employee-shareholding, 53 per cent became limited liability companies, 34 per cent became cooperatives, and the remaining 13 per cent were unclassified. Chinese law does not grant legal status to cooperatives. Interviews with the firms found that most cooperatives wanted to register as limited liability companies, but the limit on the number of shareholders (under 50) prevented them from doing so. Employees in some firms have solved this problem by pooling their shares under the name of an entrusted member.

Insider control is believed to have been one of the main problems with the Russian privatization program because insiders were reluctant to restructure firms. ${ }^{19}$ Chinese firms have also been criticized as being controlled by insiders. ${ }^{20}$ The lack of transparency in privatization programs may mask cornuption and create an

19 See Simeon Djankov and Peter Murrell, "Enterprise Restructuring in Transition", for a survey.

20 Jean C. Oi, "Patterns of Corporate Restructuring in China: Political Constraints on Privatization", The China Journal, No. 53 (January 2005), pp. 115-36. 
unjust allocation of shares within firms. The significant presence of employeeshareholding firms in the 11-city survey confirmed the popularity of insider control as a means of privatization in China.

Insiders also took over a large proportion of those firms that were sold or leased out: 16 of the 26 sales and 15 of the 58 leases involved insiders, mostly managers. Only 16 sales and 20 leases involved a private company. Overall, sales or leases to an outside private firm consisted of only 9.6 per cent of the 375 cases of gaizhi. In the summary, 10 sale and 19 lease cases were classified as "other types" of sales and leases. These cases might be a mixture of insider control and outsider participation. If these cases are included, the share of gaizhi cases that involved at least partial outsider participation rises to 15 per cent. This shows that the private sector has become an active player in gaizhi.

Table 3 shows how preferred forms of gaizhi changed over time. More firms have adopted open sales, in most cases the sale of the firm not part of its assets. Before 1995, no firm adopted open sale. Open sales have become a popular way of starting gaizhi in 2000. In 2001 and 2002, more than one-fifth of all gaizhi cases were open sales. Leasing became popular earlier. In the two most recent years, open-sales, leasing and employee-shareholding were the three most common forms of gaizhi.

Table 3: Forms of Gaizhi by Year (Number and Percentage)

\begin{tabular}{rcccccccc}
\hline \hline \multicolumn{2}{c}{$\begin{array}{c}\text { Total } \\
\text { Number }\end{array}$} & $\begin{array}{c}\text { Public } \\
\text { offering }\end{array}$ & $\begin{array}{c}\text { Internal } \\
\text { restructuring }\end{array}$ & Bankruptcy & $\begin{array}{c}\text { Employee } \\
\text { shareholding }\end{array}$ & $\begin{array}{c}\text { Open } \\
\text { sales }\end{array}$ & Leasing & $\begin{array}{c}\text { Joint } \\
\text { venture }\end{array}$ \\
\hline $\begin{array}{r}\text { Pre } \\
1995\end{array}$ & 30 & 6.7 & 20.0 & 3.3 & 30.0 & 0.0 & 16.7 & 23.3 \\
1995 & 13 & 0.0 & 23.1 & 23.1 & 7.7 & 7.7 & 7.7 & 30.8 \\
1996 & 40 & 15.0 & 22.5 & 27.5 & 17.5 & 7.5 & 10.0 & 0.0 \\
1997 & 32 & 18.8 & 37.5 & 12.5 & 25.0 & 3.1 & 3.1 & 0.0 \\
1998 & 50 & 8.0 & 34.0 & 2.0 & 28.0 & 12.0 & 16.0 & 0.0 \\
1999 & 53 & 9.4 & 34.0 & 1.9 & 30.2 & 5.7 & 17.0 & 1.9 \\
2000 & 54 & 5.6 & 20.4 & 7.4 & 31.5 & 14.8 & 18.5 & 1.9 \\
2001 & 64 & 3.1 & 7.8 & 18.8 & 29.7 & 20.3 & 20.3 & 0.0 \\
2002 & 34 & 2.9 & 11.8 & 11.8 & 23.5 & 23.5 & 23.5 & 2.9 \\
\hline \hline
\end{tabular}

Source: Survey.

Together they constituted more than two-thirds of all gaizhi cases in those two years. It is noteworthy that the popularity of employee shareholding has

21 The difference in total number of gaizhi firms reported in Tables 2 and 3 is due to the discrepancies occurred when reporting the numbers across cities (Table 2) and years (Table 3 ). 
declined in recent years. It became the dominant form of gaizhi in the late 1990s. Nearly one third in 1999 involved employee shareholding. The ratio declined to less than one quarter in 2002.

Contrary to the steadily increasing importance of open sales and leasing, the incidence of internal restructuring increased at first in the $1990 \mathrm{~s}$ but rapidly declined in the period 2000 to 2002 . Joint ventures were popular before 1996 , but have played a rather insignificant role since then. Public offering was significant in the mid-1990s, but declined considerably after that. Bankruptcy was quite popular in the mid-1990s. This was the time when the Bankruptcy Law began to be seriously implemented and the central government provided large amounts of funds to write off the bank debts of bankrupt SOEs. As a result, many SOEs used bankruptcy as a way to evade repayment of bank debts. A common practice was to file for bankruptcy and establish a new company on the same site. ${ }^{22}$ The central government quickly realized the problem and tightened up the regulation, so that the incidence of bankruptcy decreased in the late 1990s. However, as gaizhi reached its peak in $2000-01$, the incidence of bankruptcy increased again. In the current sample, 18.8 per cent and 11.8 per cent of the gaizhi cases in 2001 and 2002 respectively involved bankruptcy. Evading bank debts was still a significant motivation. The central government had to issue several decrees to block this tendency. The Supreme Court was also involved, issuing a decree making it clear that the evasion of bank debts through bankruptcy was illegal. ${ }^{23}$

\section{Privatization}

Has gaizhi led to privatization in the sense of an increase of private participation in the ownership of enterprises' capital? Table 4 shows that privatization proceeded rapidly over the sample period 1995-2001. The average proportion of private shares increased from a mere 3.5 per cent in 1995 to 33 per cent in 2001 . The percentage of firms with private shares increased accordingly, from 6.8 per cent to 43.6 per cent. Privatization accelerated from 1999, the year in which the second wave of privatization began to spread to the whole country. Management, employees and external private persons or firms were private owners of shares, and outsiders were the single largest player in all years.

By the end of 2001, 13.1 per cent of shares were held by outsiders. This trend is encouraging, as studies of other transition countries have shown that outsider participation in privatization plays a more significant role than insider participation in the improvement of firm efficiency. ${ }^{24}$ Shares controlled by

22 Shanwen Gao and Yang Yao, "Implementation of Socially Optimal Outcomes", pp. 41-58.

23 The Supreme Court (2001), Guanyu renmin fayuan zai shenli qiye pochan he gaizhi anjian zhong qieshi fangzhi zhaiwuren taofei zhaiwu de jinji tongzhi (Urgent Decree for Strictly Avoiding Debt Evasion in Trials of Enterprise Bankruptcy and gaizhi Cases in the People's Court), the Supreme Court Decree (2001) No.105.

24 See Simeon Djankov and Peter Murrell, "Enterprise Restructuring in Transition", for a survey. 
employees and by management increased at similar rates. By 2001, the two parties held almost the same amount of shares on average. Among the firms with private shares, both the amount of private shares and the number of firms in which private shares exceed 50 per cent increased during the survey period. By the end of 2001, 76.6 per cent of these firms' shares were owned by private persons, and 75.2 per cent of the firms had a majority of private shares. Increased private ownership was matched by an increased proportion of firms in which private shareholders owned controlling stakes.

Table 4: Dynamics of Privatization: 1995-2001 ${ }^{1}$

\begin{tabular}{|c|c|c|c|c|c|c|c|}
\hline \multirow[b]{2}{*}{ Year } & \multirow{2}{*}{$\begin{array}{c}\text { Private } \\
\text { Shares (\%) }\end{array}$} & \multicolumn{3}{|c|}{ Among which shares held by } & \multirow{2}{*}{$\begin{array}{c}\% \text { of gaizhi } \\
\text { firms with } \\
\text { private shares }\end{array}$} & \multicolumn{2}{|c|}{ Among which } \\
\hline & & Management & Employees & Outsiders & & $\begin{array}{c}(\%) \text { Private } \\
\text { shares }\end{array}$ & $\begin{array}{l}\% \text { privately } \\
\text { controlled }^{2}\end{array}$ \\
\hline 1995 & 3.5 & 0.0 & 0.5 & 3.0 & 6.8 & 54.6 & 52.0 \\
\hline 1996 & 4.2 & 0.1 & 1.0 & 3.2 & 7.8 & 55.6 & 51.7 \\
\hline 1997 & 5.5 & 0.5 & 1.3 & 3.8 & 10.8 & 53.2 & 48.7 \\
\hline 1998 & 9.4 & 1.2 & 2.5 & 5.6 & 16.3 & 59.5 & 55.2 \\
\hline 1999 & 14.3 & 2.7 & 3.8 & 7.9 & 22.9 & 64.0 & 59.5 \\
\hline 2000 & 23.9 & 6.9 & 7.5 & 9.6 & 33.7 & 72.2 & 70.7 \\
\hline 2001 & 33.0 & 10.0 & 9.9 & 13.1 & 43.6 & 76.6 & 75.2 \\
\hline
\end{tabular}

1. A total 387 firms were used in the calculation.

2. Over 50 per cent of shares owned privately.

Source: Survey.

In summary, gaizhi has become more radical in that it has involved more privatization in recent years, and outsiders have been playing an increasingly important role in privatization. These trends have had a lot to do with the emergence of the private sector and market liberalization in the country. Market liberalization in the early 1990s abandoned controls on prices and opened up the market to private firms. As a result, SOEs faced increasingly fierce competition from the private sector, and many of them were pushed to the verge of bankruptcy. ${ }^{25}$ In addition, banks have become more commercially oriented and have tightened their lending to SOEs ${ }^{26}$ In particular, the People's Bank of China, the central bank, issued stringent regulations related to commercial banks' loan activities in 1998 as a response to the Asian financial crisis. Local governments could no longer use SOEs to finance activities designed to advance their own objectives, such as maintaining employment. This hardened budget constraint has

25 These competitive forces forced many SOEs to restructure rather than to privatize during the 1980 s and 1990 s, leading to the emergence of some very successful SOEs, such as Haier, without privatization.

Yuanzheng Cao, Yingyi Qian and Barry Weingast, "From Federalism, Chinese Style to Privatization, Chinese Style", Economics of Transition, Vol. 7, No. 1 (1999), pp. 103-31. 
been a major cause for local governments privatising their SOEs. ${ }^{27}$ These changes have accompanied the accumulation of wealth in the private sector, which has enabled many private firms to have enough capital to buy SOEs. For example, several large SOEs in Tangshan city have been purchased by private coal mine owners.

\section{Handling SOE Assets}

Has the sale of SOE assets been handled with appropriate regard for the public interest? Or have insiders abused their positions to steal state property? These questions have been hotly debated. For example, Ding Xueliang found that restructuring has resulted in the transfer of state assets to a small number of private persons, especially the managers. ${ }^{28}$ Our survey provides insights into this important issue. Proper handling of SOE assets is related to the method of sales, asset valuation, and the way that discounts on true value are provided to purchasers. The handling of SOE debts is a related issue. Most SOE debts are owed to banks. Since most banks belong to the central government, local governments deal with debts to banks differently from the assets of SOEs which are owned by local government.

\section{Practices in the Selling of SOE Assets}

Local governments have used a number of methods to transfer state assets in gaizhi. The variations can be attributed to applications of discretionary power rather than to explicit policy, although there are some policy differences across regions. The main approach for larger and high-quality SOEs has been to issue equity through the stock market. Firms must meet stringent rules to qualify as listed companies, with the result that only the best-performing can list on the stock market. Current regulations stipulate that the state must hold the majority of shares in those listed companies, which restricts firms from becoming truly independent corporate entities. ${ }^{29}$

For smaller firms, the purchase of equity by insiders is common. Local governments often encourage managers to buy the majority of their firm's shares. Government guidelines suggest that shares sold intemally should be distributed according to rank. The largest proportion goes to senior managers, followed by technical personnel and then ordinary employees. To encourage the purchase of shares, employees are able to defer payment of two shares for each share that they buy for cash. If shareholders defer payments, they are able to receive dividends and have voting rights, but have no right to ownership, or to transfer over those shares through sale or bequest. Deferred payments have to be settled within five years. Shares are occasionally distributed to employees in lieu of wages or retirement benefits.

27 Kai Guo and Yang Yao, "Causes of Privatization in China: Testing Several Hypotheses", Economics of Transition, Vol. 13, No. 2 (2005), pp. 211-38.

28 See Xueliang Ding, "The Illicit Asset Stripping of Chinese States Firms", The China Journal, No. 43 (January 2000), pp. 1-28.

29 Stoyan Tenev and Chunlin Zhang with Loup Brefort, Corporate Governance and Enterprise Reform in China (Washington, D.C.: World Bank; International Finance Corporation, 2002). 
Government regulations also allow inventions and other intellectual property rights to be converted to shares after they have been valued and priced, dependent on the agreement of a general meeting of shareholders. The principal managers of the new state-controlled shareholding companies can fund the purchase of up to 50 per cent of the shares allocated to them by borrowing from the state asset exit funds (see below), and are obliged to repay the loan with interest within five years.

When an SOE is sold openly, the buyer needs to sign a contract with the government regarding the debts and redeployment of the employees. We found that there are different ways of deciding the price of the assets. When the firm's net asset value is positive, the sale price will be the value of the net assets. When a firm's assets and debts are more or less equal, the firm could be transferred at a zero price. When net assets are negative, the debt may be reduced to make total assets and debts more or less equal. The concession on price could be achieved by giving the new owner free land-use rights, or by making payments from the returns from state assets managed by the provincial or city government asset management agencies which have been established in dealing with state assets sales and transfer at local levels. ${ }^{30}$ Another method is to exempt the gaizhi firm from income tax until enough value has been transferred to reach zero net asset value.

The local government's main priority is the redeployment of workers who have become redundant in the process. In principle, earnings from asset sales could be used for this purpose. However, this cannot happen in cases where the SOE's net assets are negative. Three government-sponsored funds facilitate and reduce the costs of gaizhi: namely, the state asset exit funds; the SOE bankruptcy provisional funds; and the funds to assist retailers to prepare for enterprise reform. State asset exit funds provide a loan to the gaizhi firm to meet the costs of redeploying its workers. The loan must be paid back within five years. The funds are managed by authorized state asset-management agencies or by finance departments of local governments. The funding comes from the transfer of ownership rights, sale or lease of state assets.

Not all localities have the same ability to raise funds for gaizhi. Richer provinces such as Guangdong have been able to handle the costs of gaizhi more proficiently, although even there local officials are concerned about their ability to bear the costs of gaizhi, especially the costs of redeploying workers. Those regions where average incomes are low and the number of SOEs high lack adequate government funding to support gaizhi programs, and many programs have stalled. Local governments have come under increased pressure to reform their SOEs. There have been calls for greater central government support for poorer regions, or for those with a higher concentration of SOEs.

At the central level, it is the State-Owned Assets Supervision and Administration Commission (SASAC) which is responsible for carrying out enterprise restructuring in those centrally administered, large-size SOEs. SASAC is responsible for regulating the gaizhi process. It has promulgated a series of regulations dealing with the transformation of SOEs in response to the "irregularities" resulting in the loss of state assets since 2003. 


\section{Asset Valuation and Price Discounts}

The valuation of assets is the key to fair transfers of an $\mathrm{SOE}$ to a private investor. Firms must go through 3 procedures: asset valuation, the demarcation of ownership rights, and the verification of assets. Although asset valuation forms the basis for the sale or transfer of assets, discounts are often given by local governments in exchange for the new owner's consent to employ more workers.

There are several standard methods for valuing business assets: historical cost and multiples of past incomes; replacement cost; multiples of current earnings; and discounted expected cash flows. However, the lack of development of the capital market and other factors such as control over interest rates have prevented China from using some of these more sophisticated methods of asset valuation. The book value of assets is, therefore commonly used to determine the selling price. This method can either overestimate or underestimate a firm's value, but in the absence of open bidding it remains the easiest way.

Irregularities and weaknesses in the accounting industry often cause distortions in the valuation of SOE assets. The industry is fragmented because valuers specialize in particular areas, such as assets, property, land, mining rights or vehicles. In addition some agencies do not act on a commercial basis but are influenced by local governments or gaizhi firms that make requests for a favorable valuation. The choice of a valuer can be made by either the state government or by the firm. The survey found that in the first round of gaizhi undertaken by the sample firms, 39 per cent of valuers were chosen by gaizhi firms, 35 per cent by local governments, and the remaining 25 per cent jointly by local governments and firms.

Stabilizing employment in the process of gaizhi has been strongly emphasized by the central government. It is a political as well as an economic issue. As a result, local governments are prepared to do a great deal to maintain employment in the process of gaizhi. One method that has been commonly used is to exchange price discounts for the new owner's agreement to redeploy more workers. Regulations in Harbin, for example, allow the government to offer discounts when selling SOE assets. Buyers who purchase the whole business and make a one-off payment can receive a 30 per cent discount. Those making a oneoff payment covering 60 per cent of total asset value can receive a 10 per cent discount. Beyond 60 per cent of the value of assets, a half-percentage point discount can be given for every percentage point increase in payment. The first payment should not be below 30 per cent of the assessed price, and payments should be made in installments, with guarantees given before the assets are transferred.

Table 5 presents data on the discounts given to gaizhi firms by local governments. The percentage of gaizhi cases that involved a discount on the firm's assets ranged from 5.7 per cent in Harbin to 35.8 per cent in Huangshi. It is noteworthy that most firms surveyed did not want to report whether they had received a discount in gaizhi. So the figures reported in Table 5 provide only a lower limit to the true situation. 
Table 5: Discounts Provided to Gaizhi Firms by Cities (Numbers and Percentage)

\begin{tabular}{lccc}
\hline & Number of gaizhi firms & Number of rebates & Per cent \\
\hline Harbin & 35 & 2 & 5.7 \\
Fushun & 4 & 1 & 25.0 \\
Tangshan & 46 & 8 & 17.4 \\
Weifang & 25 & 7 & 28.0 \\
Lanzhou & 12 & 1 & 8.3 \\
Xining & 13 & 0 & 0.0 \\
Huangshi & 53 & 19 & 35.8 \\
Guiyang & 30 & 7 & 23.3 \\
Zhenjiang & 40 & 12 & 30.0 \\
Hengyang & 38 & 4 & 10.5 \\
Chengdu & 18 & 3 & 16.7 \\
Total & 314 & 64 & 20.4 \\
\hline \hline
\end{tabular}

Source: Survey.

\section{SOE Debts}

Most SOEs hold large debts, which must be dealt with before gaizhi is possible. As mentioned, bank debts generally make up the main item of enterprise debts, but many enterprises also have unpaid taxes, overdue wages, pensions and social insurance, and other debts. In the survey, the 493 SOEs that have valid data for 2001 owed a total of 25 billion yuan, of which bank loans with interest made up 15 billion yuan, or 59 per cent of the total. Most overdue loans were owed to the four state-owned commercial banks. Gaizhi firms have little wish to pay back debts that have been accumulated over time, and the banks lack the means to recover these loans. One example is the Hengdong Cement Factory, which borrowed 14.4 million yuan from the Industrial and Commercial Bank of China for investment in 1995. The factory performed poorly and payments became overdue in 1997. In 2001, four years and several managers later, the overdue amount, including interest, had risen to 15.9 million yuan.

Debt problems have hampered the reform of SOEs, but it is no easy task to resolve the multiple and sometimes competing concerns of gaizhi firms, banks and local governments. As one CEO in Harbin pointed out during an interview, gaizhi firms are more concerned about the debts owed to employees than about the overdue bank loans, which they see as being owed to the government by the former SOE. Even if they had originally intended to pay off the debt, most gaizhi firms find themselves unable to do so as they would struggle to stay in operation and find it difficult to attract new capital. The government has not gone as far as canceling the debts of small and medium-sized enterprises, as it did for the large SOEs. Some medium-sized SOEs in Harbin in 2002 were delaying their gaizhi programs in anticipation that the government would extend the debt write-offs and debt-equity swaps to medium-sized SOEs. 
As mentioned earlier, bankruptcy is used to escape bank debts. More than 2,000 firms have gone through bankruptcy procedures since the Bankruptcy Law was enacted in 1988. In the survey, 90 per cent of CEOs of gaizhi firms believed that bankruptcy was a feasible means of resolving their enterprise's debt problems. In response, banks have been trying to avoid losses, preferring firms not to be restructured if that is likely to involve bankruptcy. In 2002, the Supreme People's Court ruled that it would not process bankruptcy cases if the main intentions were to escape debts. ${ }^{31}$ The central government has also tightened regulations to strengthen the management of debt liabilities and to prevent firms from ignoring their debts. ${ }^{32}$ To prevent firms from using gaizhi to discharge their bank debts, a register of firms that have tried to avoid debts has been set up, and firms are given a schedule for debt repayment. If firms fail to meet the schedule, they will be unable to apply for new loans or open new bank accounts. Financial institutions can reduce the credit rating, and suspend the review of new projects and the granting of new loans for specific regions, which directly affects local government interests.

Although local banks would like to help gaizhi firms by discounting and rescheduling their debts or reducing interest payments, this would not be enough to solve the problems of gaizhi firms, as many SOEs were heavily in debt before gaizhi. Banks have been asked by the central banking authority to act as true commercial entities, making it difficult for them to give up their rights as creditors. Banks can sue enterprises to recover loans, but lawsuits often end up in a stalemate, with the banks unable to recover the loans and the firms unable to continue with restructuring. Several firms in Harbin said that gaizhi programs had stalled pending court decisions over the repayment of bank debts. As one bank manager stated: "We can sue the debtors in court, but it would not do much to get our money back because we can never get a single cent from the gaizhi firms whether we win the lawsuit or not". In some cases banks have also been reluctant to seize the assets of the gaizhi firms, because the revenue might not cover the cost of auctioning the assets. Their only recourse is to refuse to make new loans to firms that default on loan repayments.

Many gaizhi firms have not begun real gaizhi because they have refused to take over the debts of the old firm. Firms sometimes take other ways of avoiding responsibility for the debts, for instance by setting up a new private firm to lease the assets and employ most of the workers, leaving the old firm to carry the bank debts. In many cases, the old firm is left with few employees to look after the workshops and equipment and is likely to go bankrupt eventually.

In dealing with the debt problems of gaizhi firms, the interests of debtors and creditors have to be balanced. In practice, solutions that hurt the interests of either side disproportionately may not be conducive to successful gaizhi. While the government

31 Clause 12(1), "Guanyu chuli qiye pochan shenqing wenti de ruogan guiding" (Regulations on Issues of Processing Applications for Enterprise Bankruptcy), Supreme People's Court, 1 September 2002.

32 See the People's Bank of China, "Guanyu jiaqiang zhaiwu guanli, jianli fangzhi he chengfa taofeizhai tixi de tongzhi" (Notice on strengthening management of debt liabilities and building a system of preventing and penalizing the behavior of avoiding financing debts), 7 January 1997. 
needs to tackle the debt problems, it is more important that an environment is created that allows gaizhi firms to perform well so that they avoid falling into new debt traps. It is necessary to provide access to bank credit and loans if hard budget constraints are to be imposed on firms. "The imposition of hard budget constraints on enterprises in the absence of functioning credit may force sound firms into insolvency". 33

\section{Land-use Rights}

Land in China is owned by the state or, in rural and suburban areas, by collectives. Before 1995 all land-use rights for SOEs were under government control. The state being the owner of both enterprises and land, the land-use rights were not defined and the land was used free of charge by the SOEs. As a result, much of the land taken by SOEs was underutilized or misallocated. This situation continued until the 1998 Land Law, which defined land as a scarce resource and stipulated that it should be used to generate revenue. $^{34}$

At least four methods are used to deal with land-use rights in gaizhi: keeping the appropriation by the firm of the land-use rights (meaning the use free of charge of occupied land); leasing; buying; and converting land-use rights into equity. Despite the government's active encouragement for firms to buy land-use rights, many gaizhi firms prefer to maintain their appropriation of the land-use rights. The Regulation on Appropriated Land-Use Rights in SOE Reform, and the document entitled "Strengthening Land Resource Management and Promoting SOE Reform", issued by the Bureau of National Land Resource Management, have stipulated that some gaizhi firms that currently occupy land can use it free of charge on conditions set by the local government.

The usual conditions are: gaizhi firms must be operating in sectors stipulated by the government; land in use must be assessed, and any extra land must be returned to the government; the land must be used for production, and the firm's owners cannot change the land use or lease the land to others without the permission of the relevant agency; and land-use tenure is usually set for between 5 and 10 years, depending on the land use. Although land appropriation has restrictions, it can save gaizhi firms a great deal of money.

Leasing is a suitable method for gaizhi firms that cannot afford to buy granted land-use rights. To reduce the financial pressure, gaizhi firms are allowed to pay around 30 per cent of the fee up front and the remaining amount on an annual basis. Leasing has many advantages, but different cities have different practices. In some cities, gaizhi firms with leased rights were able to mortgage or use the land-use rights as collateral for a loan, while such practice was not allowed in other cities.

33 Holger Wolf, "Transition Strategies: Choices and Outcomes", Princeton Studies in International Finance, Vol. 85 (June 1999), p. 4.

34

Anthony Gar On Yeh, "Dual land market and internal spatial structure of Chinese cities", in Laurence J. C. Ma and Wu Fulong (eds), Restructuring the Chinese City: Changing Society, Economy and Space (London: Routledge, 2005). 
Finally, the method of converting land-use rights into equity is rarely used, but can complement other methods; for instance, when the government wants to retain shares in gaizhi firms and to take over the management rights, or when joint ventures are formed with foreign companies, it can own part of the firm by converting land-use rights into equity.

The survey demonstrated that maintaining appropriation was the dominant method of acquiring land-use rights in all the cities except Xining, Harbin and Huangshi. Of the 199 gaizhi firms that replied to this question, 45 per cent favored this method. The second most common method was buying the land-use rights (31 per cent), followed by leasing ( 12 per cent) and converting land-use rights into equity (6 per cent). The majority of the sample firms, particularly listed companies and restructured firms, obtained land-use rights for free. A high proportion of firms that were sold or leased out purchased the land-use rights. Non-reported cases were high across all forms of gaizhi firms.

There have been a number of problems with the way land issues have been dealt with during gaizhi. It has been difficult for the local land resource authority to manage the process of pricing the land, and its decision may not reflect the true value of the land. The decision to offer a discount on the price to the gaizhi firm has often been made arbitrarily. The different regimes of land-use rights may also create a disincentive for firms to privatise. Private firms will have to pay a significant fee to convert the allocated land-use rights into grant-use rights. Allocated land-use rights also limit the ability of gaizhi firms to obtain bank financing or to enter into joint venture arrangements with domestic or foreign partners.

The ability of the local governments to monetize the value of the land is a key factor in implementing the gaizhi programs at local level. Many local governments rely on the proceeds from the sale of land-use rights to cover the social obligations related to restructuring. The current attempts by the central government to fight overheating of land prices (in particular due to a booming real estate market) by exercising a tight control on land sales is having an effect on the pace of gaizhi programs.

\section{Financial Arrangements for Worker Settlement}

\section{The Impact of Gaizhi on Unemployment}

Enterprise restructuring has been a socially painful process. Between 1995 and 2001, the number of state-owned and state-controlled enterprises in China fell from 118,000 to 47,000 and total employment in the SOE sector fell by 36 million. The number of jobs lost totaled 15 per cent of urban employment in 2001. Over-employment had created a massive burden on SOEs now trying to shake off some of its excess workers during the gaizhi process. The number of labor disputes of all kinds rose by 12.5 per cent in 2000, and by another 14.4 per cent in 2001 to reach 155,000. In the first half of 2004 alone, labor disputes arbitration committees at various levels accepted 135,000 
labor dispute cases and handled 6,640 collective labor disputes, which involved 184,000 persons. ${ }^{35}$

The survey found that both non-gaizhi and gaizhi SOEs have lost many employees in recent years, suggesting that market competition has been exerting pressures on all firms. Table 6 shows the proportions of on-duty employees, and of retired, xiagang ${ }^{36}$ and discharged workers in 2001 in both non-gaizhi and gaizhi SOEs. Note that xiagang workers and retired workers were sometimes included in the enterprises' statistics of total employment because these workers were still being partly supported by the firm. The number of retired employees includes all those who retired in previous years. The number of xiagang workers includes those laid off in previous years but still listed by the re-employment service center and therefore still counted as employees. The statistics did not include xiagang workers who had found employment or had been removed from the re-employment service center after three years. The number of discharged employees only includes those who were discharged in 2001. Xiagang workers made up 32.7 per cent of employees in non-gaizhi SOEs but only 26.1 per cent of employees in gaizhi firms. This could be because gaizhi firms had already shed many of their xiagang workers during gaizhi.

Table 6: Shares of On-duty, Retired, Xiagang and Discharged Employees in 2001

\begin{tabular}{lcccccc}
\hline & $\begin{array}{c}\text { No. of } \\
\text { firms with } \\
\text { valid data }\end{array}$ & $\begin{array}{c}\text { Total number } \\
\text { of employees } \\
(1,000)\end{array}$ & $\begin{array}{c}\text { On duty } \\
\text { (per cent) }\end{array}$ & $\begin{array}{c}\text { Retired } \\
\text { (per cent) }\end{array}$ & $\begin{array}{c}\text { Xiagang } \\
\text { (per cent) }\end{array}$ & $\begin{array}{c}\text { Discharged } \\
\text { (per cent) }\end{array}$ \\
\hline $\begin{array}{l}\text { Sum of Gaizhi firms } \\
\text { hareholding companies }\end{array}$ & 214 & 308 & 57.1 & 16.0 & 26.1 & 0.7 \\
$\begin{array}{l}\text { Limited liability } \\
\text { companies }\end{array}$ & 119 & 190 & 62.1 & 17.5 & 19.2 & 1.2 \\
$\begin{array}{l}\text { Partnership/cooperatives } \\
\text { Single-owner private }\end{array}$ & 16 & 11 & 51.6 & 24.4 & 22.8 & 1.2 \\
firms & 2 & 0.7 & 37.0 & 9.3 & 53.7 & 0.0 \\
Other & 45 & 21 & 59.9 & 12.7 & 27.2 & 0.3 \\
Non-gaizhi SOEs & 280 & 209 & 43.9 & 22.1 & 32.7 & 1.3 \\
Total & 494 & 518 & 56.6 & 19.1 & 23.2 & 1.1 \\
\hline \hline
\end{tabular}

35 "Labor disputes on the rise", People's Daily, 1 November 2004.

36 Xiagang literally means "losing the position". An employee is called a xiagang employee if he stops working in the factory but nevertheless keeps a nominal tie with the factory through work registration. In effect, xiagang and unemployment are equivalent in terms of the status of the worker, but government policies are different for the two categories of worker. The benefit of being described as xiagang, rather than as officially unemployed, is that people are still counted as employees and may have the chance to resume working the enterprise, although in reality this does not often happen. 
Table 7: Accumulated Xiagang and Discharged Workers per Firm in the Period 1995-2001

\begin{tabular}{lcccc}
\hline & \multicolumn{2}{c}{ Xiagang $^{1}$} & \multicolumn{2}{c}{ Discharged } \\
\cline { 2 - 5 } & $\begin{array}{c}\text { Average } \\
\text { Number }\end{array}$ & $\begin{array}{l}\text { Per firm } \\
\text { percentage }\end{array}$ & $\begin{array}{c}\text { Average } \\
\text { Number }\end{array}$ & $\begin{array}{l}\text { Per firm } \\
\text { percentage }^{2}\end{array}$ \\
\hline Sum of gaizhi firms & 417 & 29 & 69 & 4.8 \\
Shareholding companies & 319 & 12 & 117 & 4.4 \\
Limited liability companies & 527 & 33 & 88 & 5.5 \\
Partnerships/cooperatives & 296 & 43 & 13 & 1.9 \\
Single-owner private firms & 245 & 70 & 0 & 0.0 \\
Other & 238 & 51 & 6 & 1.2 \\
Non-gaizhi SOEs & 515 & 69 & 37 & 5.0 \\
Total & 472 & 45 & 51 & 4.9 \\
\hline \hline
\end{tabular}

1. The number of accumulated xiagang workers is calculated under the assumption that their average stay in the re-employment service centres was three years (reflecting the difficulty of gaining employment and the provision of a subsidy over the period that acts as a disincentive to seek employment).

2. Percentage of the average number of total employees in 2001 .

However, Table 7 suggests that gaizhi firms performed better in the long run. In the table, estimates are made of the accumulated number of xiagang and discharged employees in sample enterprises over the period 1995-2001. Again there was a significantly higher share of xiagang workers in non-gaizhi SOEs compared with gaizhi firms (69 per cent versus 29 per cent). Therefore, even if they shed more workers during the year of gaizhi, gaizhi firms had accumulated significantly fewer xiagang workers after gaizhi, which means that gaizhi may improve the employment situation in the long run.

\section{Re-employment and Compensation to Laid-off Workers}

As pointed out by Oi (2005), "political economy of corporate restructuring in China is shaped by political as well as economical constraints. The political constraint is fear of worker reaction; the economic constraint is a lack of resources to fill the holes in a still-developing national social-welfare safety net, which in practice means having to buy off workers and other 'losers from reform' with acceptable severance packages. Restructuring and privatization remain a patchwork of solutions that push the limits of reform but then must be reined back to accommodate the political as well as economic realities that exist in different localities". ${ }^{37}$

Re-employment is therefore a desirable solution both for redundant workers and staff members of SOEs and for the state, because it lowers the cost of gaizhi and

37 Jean C. Oi, "Patterns of Corporate Restructuring in China", p. 135. 
reduces the political as well as economic constraints. This is why most governments give tax holidays and deductions to former SOE employees who start a business or to new enterprises that hire xiagang workers to the extent of at least 60 per cent of their workforce. Government departments and banks also help these firms with registration and access to bank loans. In some cases the government assists redundant workers to find other work, but this accounts for only a small proportion of employee redeployment. But re-employment is not always possible, and layoffs are unavoidable.

It is a difficult task to determine the level of compensation. As Roland puts it: "Some of these workers expect to find jobs easily and will not lose much from redundancies, whereas others will have a much harder time and will need to be compensated more heavily to accept being laid off. But if one cannot tell which worker is in which category, then all workers would have to be paid high compensation, because they are indistinguishable and because workers with lower exit costs have an incentive to pretend they have high exit costs" ${ }^{38}$ In reality, the level of compensation depends on the collective bargaining power of the workers and on the resources available to enterprises and local governments. Our interviews show that, while in most cities workers receive compensation equal to 3 years' salaries, in a few cases, such as Daqing Oil Fields, workers get much higher compensation.

The most common way for local governments to finance the compensation is to use the money raised in selling SOE assets. In many cases, local governments prefer the new owner to hire as many workers as possible in exchange for discounts on the price of assets (including land). Many enterprises are sold at zero value, and in some cases the government pays extra subsidies to cover the redeployment of the employees. One example is the city of Tangshan where buyers of SOEs must agree to take responsibility for all employees and retired workers. ${ }^{39}$ The government compensated buyers for the future cost of redeploying workers by reducing the price of the assets on the understanding that no more than 10 per cent of employees will be made redundant. The new owners frequently reported that the compensation was inadequate as the cost of redeploying workers was much higher. However, there were also complaints from employees that state assets such as land were being sold too cheaply. ${ }^{40}$ In Harbin, the municipal government allowed enterprises going through gaizhi to sell part of their assets to compensate employees who are being discharged. Land-use rights can be transferred if funds are inadequate.

Gerard Roland, "The Political Economy of Transition", Journal of Economic Perspectives, Vol. 16, No. 1 (2002), pp. 29-50.

39 Workers and staff members retired from SOEs are covered by the new pension system. However, pension payments are low, perhaps lower than the common pension rate in SOEs. Enterprises still have to pay the difference between the actual and common pension rate.

40 The survey found only a few cases in different cities of new owners complaining about the overvaluation of state assets. 
Nan'an District of Chongqing City adopted a different approach. ${ }^{41}$ The employment contracts of all SOE employees were terminated and workers compensated before the enterprises were sold or went bankrupt, regardless of whether workers will be re-employed by the new owners of the enterprises or not. This makes gaizhi much easier and reduces conflicts after gaizhi. A large percentage of the district's SOEs have completed gaizhi. The proportion of enterprises that has completed gaizhi is much smaller in the other districts, which adopted a municipal government policy of redeploying employees after the enterprise goes bankrupt. In these districts, state assets are used to pay off debt, leaving little for employee redeployment. If governments wish to compensate the employees before gaizhi, they need the agreement of the creditor banks and usually there needs to be a large positive net value of state assets to cover the costs of employee redeployment. In Nan'an District, land values are high and the sale of land-use rights has financed redeployment.

Guiyang has adopted a policy that allows employees more say. In the city, gaizhi plans have to pass a vote of the employee conference or employee representative committee. Employees must agree with the decision to terminate their contracts. They should receive a lump-sum payment of two months' wages for every year of service. Such comparatively generous conditions, not common elsewhere, make the gaizhi process more difficult, because employees are likely to block the decision to undergo gaizhi until the situation becomes so bad that no wages can be paid. These provisions may explain why the private sector in Guiyang is underdeveloped. Guiyang is also a very poor place in which the social role of SOEs is probably more important than elsewhere. The development of the private sector in the local economy helps provide employment opportunities for redundant state workers and is a crucial factor for the success of gaizhi.

\section{Impacts of Restructuring on Firm Performance}

\section{Financial Discipline}

Soft budget constraint has been one of the most serious problems to plague SOEs in the former centrally planned economies. Kornai suggests that a soft budget constraint arises as a consequence of state paternalism towards the socialist firm, so it is expected that gaizhi, and privatization in particular, will alleviate the problem. ${ }^{42}$ However, a soft budget constraint can also exist in a capitalist economy, due to the banks' and the state's failure to commit to a time-consistent policy. ${ }^{43} \mathrm{Can}$ we expect

4) Only face-to-face interviews were conducted but no questionnaires were distributed in this city.

42 Soft budget constraints result from the lack of discipline which derives, for example, from the unenforceability of bankruptcy, together with various subsidies, credits, and price supports provided by the state to SOEs. See Janos Kornai, Economics of Shortage (Amsterdam: North-Holland Pub. Co., 1980); Janos Kornai, "The Soft Budget Constraint", Kyklos, Vol. 39, No. 1 (1986), pp. 3-30.

43 M. Dewatripont and Eric Maskin, "Credit and Efficiency in Centralized and Decentralized 
gaizhi and privatization to improve a firm's financial discipline? Here we compare gaizhi and privatized firms with the old-style SOEs using three financial indicators: performance on meeting obligations on bank debts, taxes, and social security. The first indicator reflects the firm's relationship with the bank, and the other two reflect its relationship with the government. When a firm can postpone its due payments to the bank or the government the constraint on its budget is soft. So we study overdue bank debts (overdue bank loan repayments plus the arrears in interest payments), overdue taxes and overdue social security.

Table 8 compares gaizhi firms with non-gaizhi firms with regard to the above three indicators. The first three columns of the table show the percentage of firms with overdue payments; the last three columns show the average amount of overdue payments weighted by appropriate denominators. It is evident that a smaller number of gaizhi firms than non-gaizhi firms owed overdue bank debts, and the average size of their debts was smaller than non-gaizhi firms although the difference seems to have decreased over time. However, this better discipline of gaizhi firms may be a result of their reduction of bank and other debts in the year of gaizhi. There is a widely shared suspicion that firms use gaizhi to evade debts.

Nevertheless, there were only 8.3 per cent and 13.6 per cent respectively of the gaizhi firms in the sample, that reduced their bank debts and all forms of debts in the year of gaizhi. So the better performance of gaizhi firms was unlikely to have been a result of debt evasion in the year of gazhi. Gaizhi has indeed hardened firms' budget constraint with the bank by imposing more discipline on these firms. It has also hardened firms' budget constraint with the government, but to a much lesser extent. A smaller number of gaizhi firms owed taxes to the government, and the average size of their overdue taxes was smaller than for other firms, but the differences were much smaller than in the case of bank debts. The advantage of gaizhi was even less clear in the case of social security. The percentage of gaizhi firms with overdue social security did not significantly differ from that of non-gaizhi firms, and the average size of their overdue social security was even larger than that of non-gaizhi firms.

Table 9 compares firms in which the private share of ownership is increasing with fully state-owned firms. In this table, a "privatized" firm is one in which any ownership shares are held privately. The comparison shows results similar to those in the comparison of gaizhi and non-gaizhi firms, but the advantage of privatized firms over fully state-owned firms has been strengthened in the case of overdue bank debts and overdue social security. This shows that gaizhi with privatization works better than gaizhi without privatization in terms of hardening firms' budget constraint.

Economies", Review of Economic Studies, Vol. 62, No. 4 (1995), pp. 541-55. Dewatripont and Maskin (1995) borrow the phrase "time-consistent policy" from macroeconomics. It refers to a situation where it would be optimal for the bank to impose tough financial discipline over the firm but, once the firm becomes insolvent, it becomes rational for the bank to issue more credit to enable the firm to bring back some returns. 

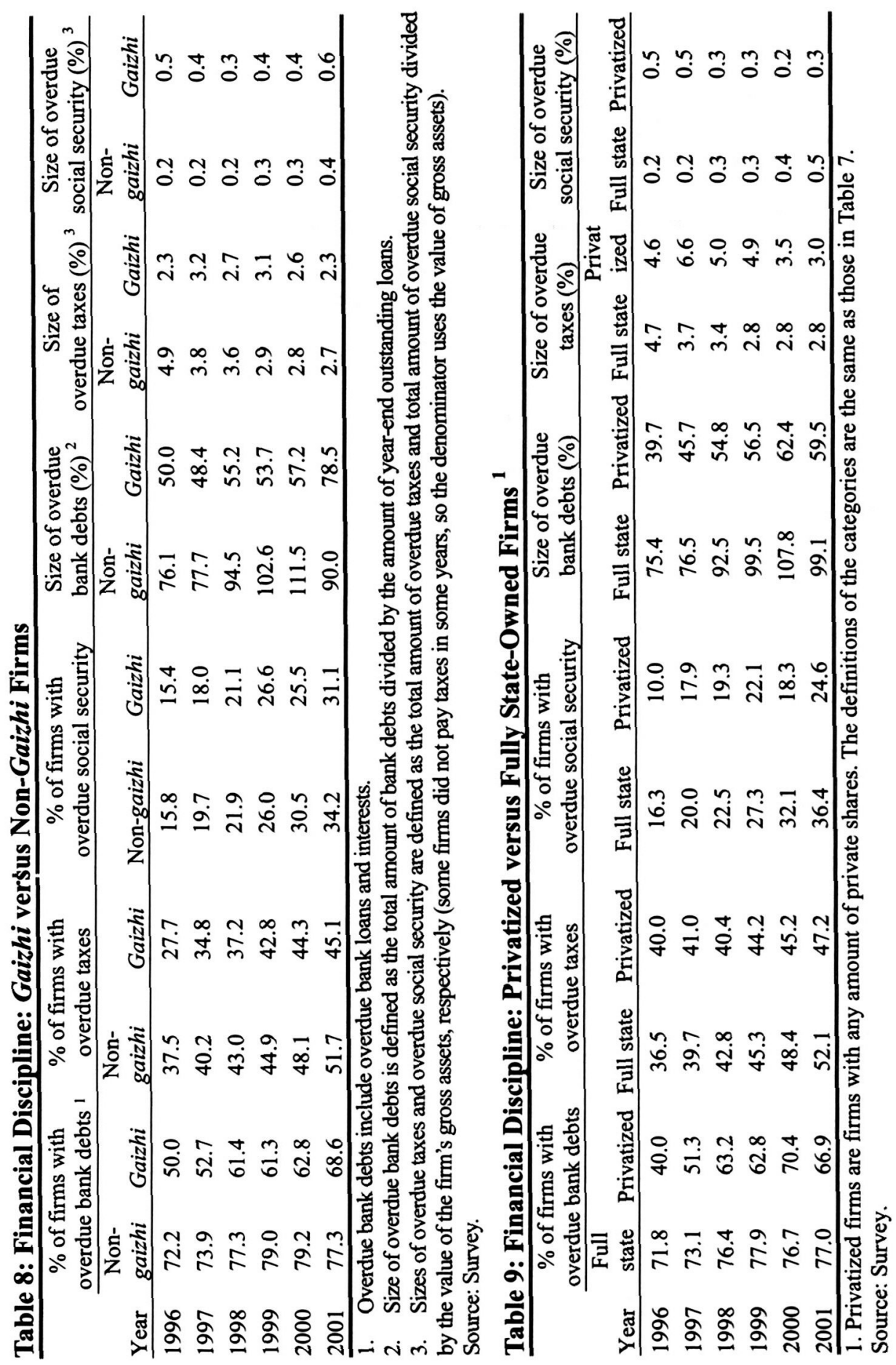


\section{Efficiency}

Gaizhi firms, especially truly privatized firms, were subject to a harder budget constraint than non-gaizhi firms. But were they more productive? This sub-section compares gaizhi and non-gaizhi firms in the sample with regard to three performance indicators: return to assets, per worker sales and new investment.

Table 10: Performance: Gaizhi versus Non-Gaizhi Firms

\begin{tabular}{lcccccc}
\hline & \multicolumn{2}{c}{$\begin{array}{c}\text { Return to assets } \\
(\%)\end{array}$} & \multicolumn{2}{c}{$\begin{array}{c}\text { Per-worker sales } \\
(1,000 \text { yuan) }\end{array}$} & \multicolumn{2}{c}{$\begin{array}{c}\text { New investment } \\
(\%)\end{array}$} \\
\cline { 2 - 7 } Year & Non-gaizhi & Gaizhi & Non-gaizhi & Gaizhi & Non-gaizhi & Gaizhi \\
\hline 1996 & -1.3 & 1.8 & 5.2 & 4.0 & 17.0 & 17.9 \\
1997 & -1.4 & 1.9 & 4.7 & 5.4 & 16.0 & 21.0 \\
1998 & -1.9 & 1.4 & 5.2 & 5.5 & 16.5 & 19.2 \\
1999 & -1.8 & 1.5 & 5.3 & 5.7 & 16.8 & 16.5 \\
2000 & -1.8 & 1.2 & 5.5 & 6.1 & 16.4 & 16.4 \\
2001 & -1.5 & 0.6 & 5.9 & 6.8 & 17.9 & 15.3 \\
\hline \hline
\end{tabular}

1. Return to assets is defined as the pre-tax profit divided by the value of the firm's gross assets.

2. It is defined as sales value divided by on-duty workers. The value of sales is converted to 2001 yuan.

3. New investment divided by the value of the firm's gross assets.

Source: Survey.

The results are presented in Table 10. Gaizhi firms are shown to do better than non-gaizhi firms with regard to return to assets and marginally better in per-worker sales, but remain indistinguishable from non-gaizhi firms with regard to new investment. Gaizhi firms' better performance was made possible not so much by more investment, but rather by efficiency enhancement.

Table 11: Performance: Privatized versus Fully State-Owned Firms

\begin{tabular}{lcccccc}
\hline \hline & \multicolumn{2}{c}{$\begin{array}{c}\text { Return to assets } \\
(\%)\end{array}$} & \multicolumn{2}{c}{$\begin{array}{c}\text { Per-worker sales } \\
(1,000 \text { yuan })\end{array}$} & \multicolumn{2}{c}{$\begin{array}{c}\text { New investment } \\
(\%)\end{array}$} \\
\cline { 2 - 7 } Year & Full state & Privatized & Full state & Privatized & Full state & Privatized \\
\hline 1996 & -1.2 & 2.5 & 5.0 & 6.8 & 16.6 & 20.8 \\
1997 & -1.4 & 3.2 & 4.7 & 5.7 & 15.7 & 14.7 \\
1998 & -1.9 & 4.2 & 5.2 & 6.1 & 15.8 & 15.0 \\
1999 & -2.0 & 4.1 & 5.2 & 6.9 & 16.2 & 12.7 \\
2000 & -2.2 & 3.7 & 5.1 & 7.8 & 16.2 & 11.4 \\
2001 & -2.1 & 2.4 & 5.5 & 7.3 & 17.8 & 11.0 \\
\hline \hline
\end{tabular}

1. Return to assets is defined as the pre-tax profit divided by the value of the firm's gross assets.

2. It is defined as sales value divided by on-duty workers. The value of sales is converted to 2001 yuan.

3. New investment divided by the value of the firm's gross assets.

Source: Survey. 
Table 11 shows the comparison between privatized and fully state-owned firms. The effect of gaizhi was enhanced in terms of return to assets when it was accompanied by privatization, but differences based on ownership are not very significant for per-worker sales, and privatized firms are shown to invest less than fully state-owned firms. The results are subject to one qualification. It is possible that better performing firms have been deliberately chosen to undergo gaizhi and privatization either because local governments believe that they can improve performance and receive a higher price by delaying privatization of poorly performing enterprises or simply because better performing firms are easier to privatize. To accommodate this consideration, we calculate the effect of privatization by adopting the difference-in-difference (DID) method. This method compares privatized firms' relative performance before and after privatization, and the relative performance of fully state-owned firms over the same years. The method is an effective nonparametric method to control firm specific characteristics. Figure 3 summarizes the results. It shows the average effect of privatization for firms privatized in different years, being arranged by years after privatization.

Figure 3: The Effect of Privatization Calculated by DID Method.

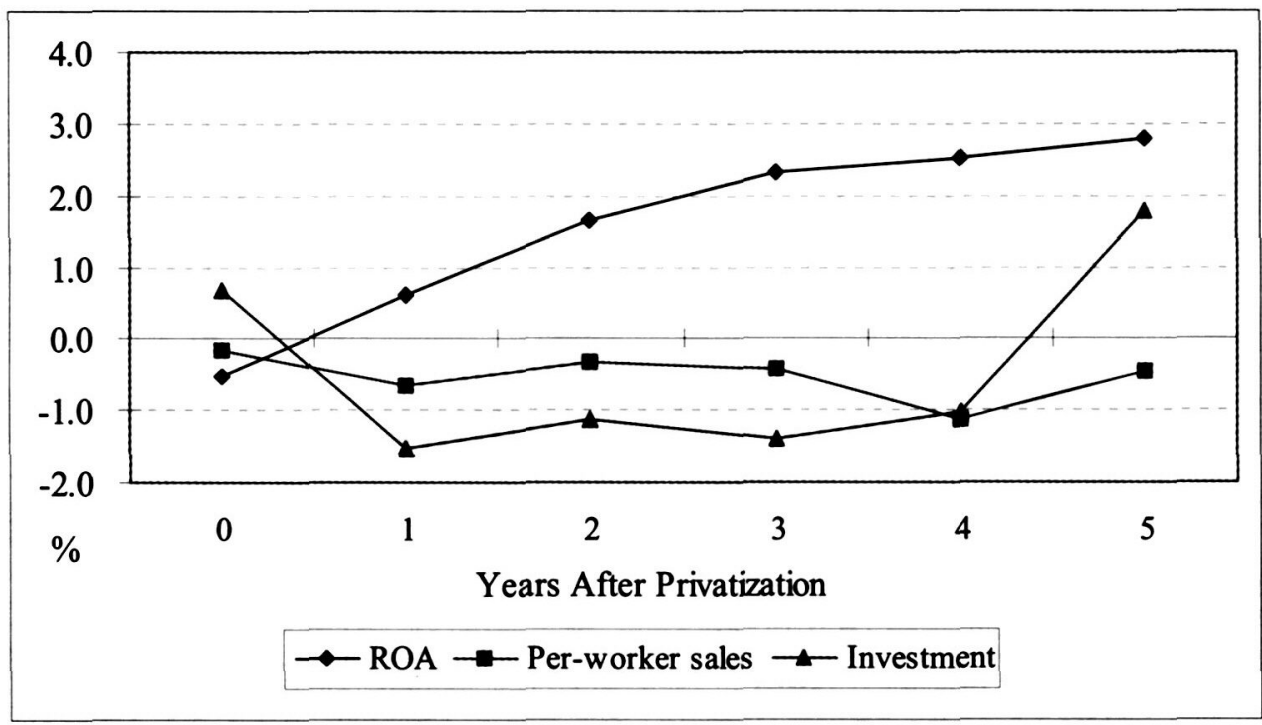

The calculation is based on the sample of 387 firms.

ROA stands for return to assets.

Source: Calculated using survey data.

Two patterns emerge from the figure. First, privatization has a significantly positive effect on return to assets, and this effect increases as time passes. There is clearly a learning process for privatization to become effective in raising profitability. The new owners need to change the management structure, adopt new business models, and possibly shift to a new line of business. Second, privatization does not result in a significant positive, and might in fact have a 
negative impact on labor productivity and investment. Indeed, gaizhi firms perform worse than non-gaizhi firms for most years after gaizhi. These two results suggest that privatized firms were more conscious than the old-style SOEs about saving costs. It is well known that traditional SOEs were used to an expansionary business model that pays little attention to saving capital, material and wage costs. Privatization changes this model. Firms no longer pursue the goal of high growth in output and investment, but rather focus on a more efficient use of financial and human resources to generate more profits. In other words, the improved efficiency of gaizhi firms comes mostly from adopting new technologies, new product combinations and more efficient ways of production.

\section{Conclusions}

This study reveals an accelerating trend of privatization in China. Firms have adopted more radical forms of restructuring in recent years and the extent of privatization has deepened. By 2001, 43.6 per cent of the sample firms had introduced private shares, and among these firms two-thirds had a majority of private shares. While restructuring is frequently criticized for leading to the loss of state assets, this paper finds that the loss has happened mainly in the form of price discounts which local governments gave to the new owners in exchange for their consent not to sack many workers. In other words, the loss of state assets, if any, is partly a result of the government's emphasis on maintaining employment.

Contrary to the conventional wisdom is another finding that gaizhi, or restructured firms, have maintained a slower rate of employment reduction than pure SOEs in the years after gaizhi, although in the year when gaizhi happened they did sack more workers. This shows that privatization has the potential to improve China's employment situation in the long run. This is made possible because privatization has led to efficiency improvements. We have found that gaizhi, especially restructuring with privatization, has hardened firms' budget constraints with the banks and significantly improved firms' profitability. As firms' investment rate and labor productivity measured by per-worker sales have not been improved in a significant way, we conclude that the positive effect of gaizhi and privatization on firms' profitability has been made possible by firms' shift from the expansionary business model characterizing the old style SOEs to a new business model that gives higher priority to cost-saving.

However, we find that restructuring has not hardened firms' budget constraints with the government. One explanation is that local governments want to trade tax and social security amenities for firms' incentive to maintain employment. This can be a rational choice, as employment is the top priority that the central government puts on restructuring. Another explanation is that local governments themselves have a soft-budget constraint with the central government. Although China has separated local and central taxes, quotas are still placed on local governments regarding the growth of tax revenues. However, these quotas are subject to negotiation. In the case of social security, the central government has established a fund preparing for unexpected payment shortfalls in the social security system. It has also provided funds to individual provinces 
for them to migrate from the old pay-as-you-go system to the new system with both public and individual accounts.

Two important issues are not studied in this paper. One is corporate governance. Restructuring will create many firms with dispersed shares held by many small shareholders most of whom are employees. A proper corporate governance structure thus is very important for these firms' future performance. Judging by the findings on private firms, ${ }^{44}$ we expect no easy task for privatized SOEs to handle corporate governance issues properly. The other issue is related to the capital market. Currently local capital markets are very thin in China, but we will soon see the demand for opportunities to trade employees' shares obtained through privatization. This increases the need for an efficient local capital market.

44 Ross Garnaut, Ligang Song, Yang Yao and Xiaolu Wang, Private Enterprise in China, (Canberra: Asia Pacific Press 2001); Neil Gregory, Stoyan Tenev and Dileep Wagle, China's Emerging Private Enterprises: Prospects for the New Century (Washington: International Finance Corporation, 2000). 


\section{CONTRIBUTORS TO THIS ISSUE}

Joel Andreas is Assistant Professor of Sociology at Johns Hopkins University. He studies changes in class relations in China since 1949. He recently finished a book manuscript analyzing the contentious merger of old and new elites in China during the communist era, and is currently investigating changing labor relations in Chinese factories between 1949 and the present.

Geremie R. Barmé is a professor of Chinese history and an Australian Research Council Federation Fellow in the College of Asian and Pacific Studies, The Australian National University. His latest work is Sang Ye's oral history, China Candid: the People on the People's Republic (Berkeley: University of California Press, 2006), edited with Miriam Lang.

Gregor Benton is Professor of Chinese History at Cardiff University. His most recent book (done with Hong Liu) is Diasporic Chinese Ventures (Routledge 2004).

Timothy Cheek is Professor and Louis Cha Chair in Chinese Research at the Institute of Asian Research, University of British Columbia and editor of Pacific Affairs. His research in modern Chinese history focuses on the public role of intellectuals and CCP Party history. He can be reached at: t.cheek@ubc.ca.

Lowell Dittmer is Professor of Political Science at the University of California at Berkeley and editor of Asian Survey, has written or edited Sino-Soviet Normalization and Its International Implications (1992), China's Quest for National Identity (with Samuel Kim, 1993), China Under Reform (1994), Liu Shaoqi and the Chinese Cultural Revolution (rev. ed., 1997), (with Haruhiro Fukui and Peter N.S. Lee), Informal Politics in East Asia (Cambridge, 2000), and many scholarly articles. His most recent book is South Asia's Nuclear Security Dilemma: India, Pakistan, and China (Armonk: M. E. Sharpe, 2005).

Ross Garnaut is Professor of Economics in the Division of Economics of the Research School of Pacific and Asian Studies, and Chairman of the China Economy and Business Program at the Australian National University. He was Australia's Ambassador to China from 1985 to 1988. His research interests are the Australian economy, regional economic integration and the Chinese economy.

Randy Peerenboom is a Professor of Law at UCLA Law School. He has been a consultant to the Ford Foundation and the Asian Development Bank on legal reforms and rule of law in China. His most recent books include China Modernizes: Threat to the West or Model for the Rest? (forthcoming 2006) 
and China's Long March toward Rule of Law (Cambridge University Press, 2002); Human Rights in Asia (Peerenboom, Petersen \& Chen eds., Routledge 2006); Asian Discourses of Rule of Law (ed., RoutledgeCurzon2004).

Ligang Song is Senior Fellow at the Asia Pacific School of Economics and Government, and Director of the China Economy and Business Program at the Australian National University. His research interests are applied international trade studies and the Chinese economy.

Steve Tsang is Louis Cha Fellow and University Reader in Politics at St Antony's College, Oxford University. His most recent books are: The Cold War's Odd Couple: The Unintended Partnership between the ROC and the UK, 1950-1958 (I.B. Tauris, 2006), and (ed.) If China Attacks Taiwan: Military Strategy, Politics and Economics (Routledge, 2006). He is currently working on a biography of Chiang Kai-shek.

Yang Yao is Professor of Economics and Deputy Director of the China Center for Economic Research at Peking University. His major research areas are transition and development in China. 